\title{
Effector Biology in Focus: A Primer for Computational Prediction and Functional Characterization
}

\author{
Ronaldo J. D. Dalio', John Herlihy², Tiago S. Oliveira', John M. McDowell2, and Marcos Machado', \\ ${ }^{1}$ Citrus Biotechnology Lab, Centro de Citricultura Sylvio Moreira, IA, Cordeirópolis-SP, Brazil; and ${ }^{2}$ Department of Plant \\ Pathology, Physiology and Weed Science, Virginia Tech, Blacksburg, VA, 24061-0329, U.S.A.
}

Accepted 1 October 2017.

\begin{abstract}
Plant-pathogen interactions are controlled by a multilayered immune system, which is activated by pathogen recognition in the host. Pathogens secrete effector molecules to interfere with the immune recognition or signaling network and reprogram cell structure or metabolism. Understanding the effector repertoires of diverse pathogens will contribute to unraveling the molecular mechanism of virulence and developing sustainable disease-control strategies for crops and natural ecosystems. Effector functionality has been investigated extensively in only a small number of pathogen species. However, many more pathogen genomes are becoming available, and much can be learned from a broader view of effector biology in diverse pathosystems. The purpose of this review is to summarize methodology for computational prediction of protein effectors, functional characterization of effector proteins and their targets, and the use of effectors as probes to screen for new sources of host resistance. Although these techniques were generally developed in model pathosystems, many of the approaches are directly applicable for exploration and exploitation of effector biology in pathosystems that are less well studied. We hope to facilitate such exploration, which will broaden understanding of the mechanisms that underpin the biological diversity of plant-pathogen interactions, and maximize the impact of new approaches that leverage effector biology for disease control.
\end{abstract}

\section{PATHOGENS HAVE EVOLVED EFFECTORS TO COPE WITH A ROBUST PLANT IMMUNE SYSTEM}

Plants must be able to quickly neutralize attacks by a wide variety of microbes, nematodes, and insects. Coevolution with these attackers has produced an immune surveillance system comprising pattern-recognition receptors that recognize microbeassociated molecular patterns and activate a basal defense called pattern-triggered immunity (PTI), a state that prevents further colonization of the host by so-called nonadapted pathogens (Jones and Dangl 2006; Macho and Zipfel 2014). Contrastingly, adapted pathogen lineages have evolved effectors that are encoded by pathogen virulence genes and secreted from pathogen invasion structures. These molecules act in a variety of locations, outside and inside plant cells, to overcome PTI and promote effectortriggered susceptibility. Effector proteins are now known to have

${ }^{\dagger}$ Corresponding author: M. Machado; E-mail: marcos@ccsm.br

๑) 2018 The American Phytopathological Society diverse cellular functions, including toxins, degradative enzymes, hormones, transcription factors, and others (de Wit 2016; Toruno et al. 2016). Pathogens can continuously develop novel repertoires of effector molecules that interfere with recognition or defense in an "arms race" during interaction with their host (Karasov et al. 2014; Marín et al. 2013).

In turn, plants have evolved disease resistance genes (long known as " $R$ genes") (Flor 1956) that perceive effector molecules and, in turn, activate the immune regulatory network. Perception of effectors can occur directly (i.e., through protein-protein interactions) or through indirect detection of perturbations in host cells (Cui et al. 2015). Upon effector recognition, a more complex defense system called effector-triggered immunity (ETI) is induced. This was elegantly summarized in the zig-zag model of Jones and Dangl (2006), and comprises a molecular explanation of the gene-for-gene model, in which avirulence (Avr) genes encode effectors that are recognized by a corresponding host $R$ gene (Bent and Mackey 2007; Flor 1971). Both PTI and ETI induce similar defense programs that often include production of antimicrobial compounds, callose accumulation, hormonal alteration, and localized plant cell death, which limit pathogen progression (Bigeard et al. 2015; Cui et al. 2015). ETI is regularly more prolonged than PTI and, at least in certain cases, can be activated more quickly and robustly. Additional information about the mechanisms and evolution of the plant immune system can be found in recent reviews.

\section{MAJOR CATEGORIES OF PROKARYOTE AND EUKARYOTE EFFECTORS}

Every class of plant pathogen or pest, from bacteria to nematodes, has independently evolved diverse mechanisms to export effectors to host cells. For instance, bacteria deliver effectors through specialized secretion systems (see below) (Tseng et al. 2009). Some fungal species have developed novel invasive structures, commonly referred to as haustoria or biotrophic interface complexes, that directly interact with host cells to deliver effectors (Khang et al. 2010). Similarly, oomycetes secrete effectors from hyphae and haustoria (Kale and Tyler 2011). This independent evolution of effector-delivery mechanisms underscores the selective advantages provided to pathogens by the ability to secrete host-targeted molecules. Effectors have been studied most intensively in prokaryotes, because of experimental convenience. Bacterial effectors are generally classified according to the secretion system through which they are secreted. Type III, IV, and VI secretion systems are the most common mechanisms associated with effector secretion (Ma et al. 2014; McCann and Guttman 2008). Distinctively, type I, II, and V 
secretion systems secrete toxins and hydrolytic enzymes (cellulases, amylases, proteases, phosphatases, lipases, nucleases, and so on) (Cambronne and Roy 2006). Type III effectors constitute the best-studied class of bacterial effectors, and can perform diverse molecular functions within host cells (Deslandes and Rivas 2012). Phytoplasmas, as intracellular organisms, secrete effectors via general SecA-dependent proteins (Sugio et al. 2011). A single effector can be a multifunctional protein and target several cell components, such as AvrB of Pseudomonas syringae, which promotes phosphorylation of RIN4/RIPK/ RAR1/MPK4 and mediates suppression of PTI responses (Cui et al. 2010; Lee et al. 2015). Effectors can also have redundant roles, such as AvrB and AvrRpm1 of $P$. syringae, which interfere with the function of the plant protein RIN4 by different mechanisms, thereby inhibiting basal defenses (Kim et al. 2005; Liu et al. 2011; Xu et al. 2017).

Eukaryote pathogens can produce hundreds of effectors that target different cell components and are generally classified as apoplastic effectors (which act in the extracellular milieu) or cytoplasmic effectors (which act in the symplastic compartment) (Stotz et al. 2014). Apoplastic effectors are often cysteine-rich, small proteins that can act as cell-wall-degrading enzymes, expansins, protease inhibitors, quenchers of the recognition of the pathogen by the plant, and more (Hann and Boller 2012). Cytoplasmic effectors also have diverse functions (Win et al. 2012). Classic examples of cytoplasmic effectors are the RxLR and Crinkler (LxLFLAK) effectors of oomycetes. These effectors have been shown to contribute to suppression of plant immunity and other functions (Anderson et al. 2015; Stassen and Van den Ackerveken 2011).

Knowing the effector repertoires of one pathogen may contribute to unravel the molecular mechanism underpinning the interaction with its host. Furthermore, several studies have demonstrated that blocking, silencing, or deleting a group of effectors, or even only one of them, can totally compromise the pathogen virulence (Bos et al. 2010; Dalio et al. 2017; Yu et al. 2012). This opens a whole new horizon to design control strategies to secure crops and natural ecosystems. In this scenario, the importance of efficiently predicting candidate effectors of a given pathogen is evident. In recent years, several in silico approaches were developed to unravel the effector repertoire in the pathogen's genome.

\section{COMPUTATIONAL PREDICTION OF PROTEIN EFFECTORS}

With the advent of new genome sequencing methods and the rising number of sequenced pathogen genomes, sophisticated computational approaches have been developed for predicting candidate-secreted effector proteins (CSEP) in genomes of eukaryotic pathogens (Fig. 1; Tables 1, 2, and 3) (Sperschneider et al. 2015). Due to the paucity of conserved sequences and structural features unifying protein effectors, the prediction of CSEP has been based on the systematic use of tools and web servers for protein sequence analyses and criteria generally found in CSEP (Sonah et al. 2016). These criteria are based on primary protein sequences and amino acid composition, which include presence of a secretion signal, no transmembrane (TM) domain or membrane anchors, reasonably small size (5 to $50 \mathrm{kDa}$ ), and other secondary characteristics such as experimentally validated effector motifs, nuclear localization signal, genomic localization (gene-sparse regions), three-dimensional structure, positive selection, species-specific sequences, absence in related, nonpathogenic species, and evidence for diversifying selection.

Generally, the first step for classification of CSEP is the prediction of extracellular secretion signals. The secretion signal peptide (SP) is an N-terminal peptide, usually 15 to 40 amino acid residues in length, comprising a tripartite structure: a hydrophylic n-region positively charged, a hydrophobic hregion, and a c-region containing the cleavage site for peptidase (von Heijne 1998). The SP can also be called targeting signal, transit peptide, or leader peptide. This motif directs the protein inside the cell to the rough endoplasmic reticulum. During secretion, this peptide is cotranslationally cleaved and the mature protein is exocytosed from the cell via the Golgi. Despite

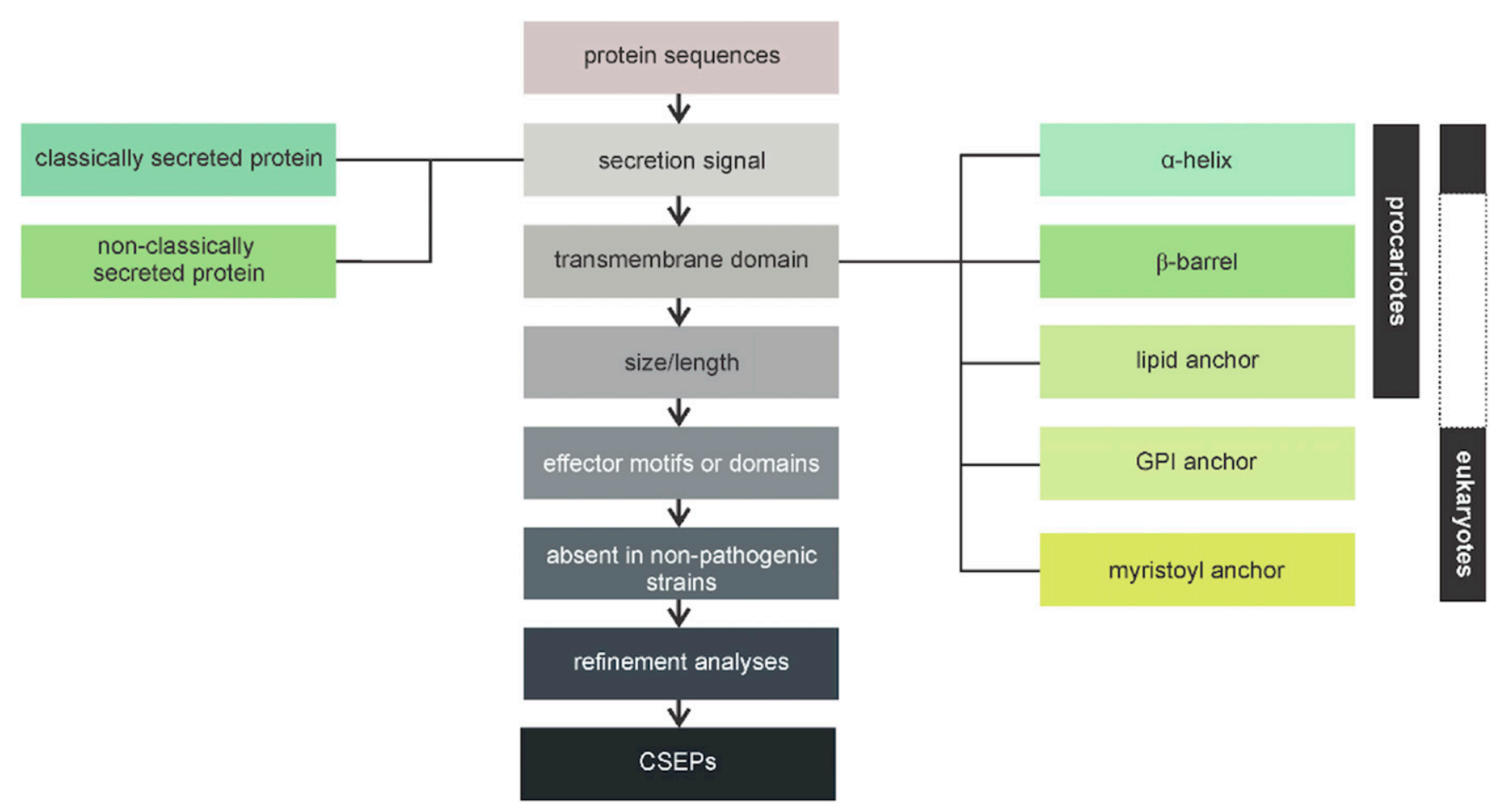

Fig. 1. General pipeline for prediction of candidate-secreted effector proteins. 
common features found in SP, their properties differ between eukaryotes and gram-negative and gram-positive bacteria (Nielsen et al. 1997). Several tools are available for predicting the SP and they usually are based on machine learning approaches such as neural networks and hidden Markov models (Table 1) (Petersen et al. 2011). The main premise here is that effectors are secreted proteins; hence, the prediction of SP.

It is important to bear in mind that some proteins are secreted by nonclassical pathways, and do not have signal peptides. Examples of pathogen effectors without a recognizable signal peptide have been documented (Liu et al. 2014). It is possible to predict bacterial nonclassically secreted protein using the tool SecretomeP (Bendtsen et al. 2004, 2005) based on structural properties usually found in these proteins. SignalP is often used to predict CSEP having SP and, according to Sperschneider et al. (2015), the versions SignalP 2 and 3 are preferred to predict fungal and oomycete secreted proteins.

Another caveat to SP-based predictions is that the presence of an SP does not guarantee that a protein is secreted. The SP may also direct the traffic of proteins to cytoplasmic organelles. It is important to distinguish them from TM helices (Reithinger et al. 2013; Robinson et al. 2012). Proteins having a TM helix are likely to have a function in the cellular membrane and, therefore, are static; this kind of protein was not present in the CSEP pool of a microorganism (Sonah et al. 2016). The high similarity between the hydrophobic region of TM helices and that of SP h-regions might cause problems. In this case, TM predictors might erroneously classify SP as TM helices, or SP predictors classify TM helices as SP. Several prediction servers are available to predict TM domains and should be an integral part of any pipeline to predict CSEP (Table 2).

Proteins can be attached to membrane complexes (plasma membrane, endoplasmic reticulum, or Golgi complex) by several mechanisms (Chrispeels 1991). In eukaryotes, for example, a glycosylphosphatidylinositol (GPI) acts as a membrane anchor confined to the $\mathrm{C}$ terminus of the targeted protein after cleavage of a signal sequence that directs GPI anchoring (Mayor and Riezman 2004). Secretory proteins can also be attached to the membrane complex by $\mathrm{N}$-terminal $\mathrm{N}$-myristoylation modifications, usually added to glycine residues that increases their total hydrophobicity, and contributes to protein and membrane association (Maurer-Stroh et al. 2002). In prokaryotes, lipoproteins have a special signal peptide that targets the protein to the lipoprotein outer membrane localization pathway machinery, and its

Table 1. Common bioinformatics tools available for prediction of secretion signals ${ }^{\mathrm{a}}$

\begin{tabular}{|c|c|c|}
\hline Tool & Description & Website \\
\hline SignalP server & $\begin{array}{l}\text { Predicts the presence and localization of } \\
\text { signal peptide cleavage site in amino acid } \\
\text { sequences from different organisms. } \\
\text { Prediction is based on a combination of } \\
\text { several artificial neural networks. }\end{array}$ & http://www.cbs.dtu.dk/services/SignalP/ \\
\hline Phobius web server & $\begin{array}{l}\text { This method combines transmembrane } \\
\text { topology and signal peptides predictions, } \\
\text { provides an optimal choice between } \\
\text { transmembrane segments and signal } \\
\text { peptides, and also allows constrained a } \\
\text { homology-enriched predictions. }\end{array}$ & http://phobius.cgb.ki.se \\
\hline Philius web server & $\begin{array}{l}\text { Predicts transmembrane topology and signal } \\
\text { peptide using dynamic Bayesian networks. }\end{array}$ & http://www.yeastrc.org/philius \\
\hline Spoctopus & $\begin{array}{l}\text { Combines prediction of signal peptides and } \\
\text { membrane protein topology. }\end{array}$ & http://octopus.cbr.su.se/ \\
\hline Signal Blast & $\begin{array}{l}\text { Predicts signal peptides based on sequence } \\
\text { alignment. }\end{array}$ & $\begin{array}{l}\text { http://sigpep.services.came.sbg.ac. } \\
\text { at/signalblast.html }\end{array}$ \\
\hline PrediSi & $\begin{array}{l}\text { Method based on a position weight matrix } \\
\text { approach improved by a frequency } \\
\text { correction that takes the amino acid bias } \\
\text { present in proteins in consideration. The } \\
\text { software is trained using sequences from } \\
\text { SwissProt database. }\end{array}$ & http://www.predisi.de/home.html \\
\hline Signal-CF & $\begin{array}{l}\text { An automated method for predicting signal } \\
\text { peptide sequences and their cleavage site. }\end{array}$ & $\begin{array}{l}\text { http://www.csbio.sjtu.edu.cn/bioinf/Signal- } \\
\text { CF/ }\end{array}$ \\
\hline Signal-3L & $\begin{array}{l}\text { Consists of three prediction engines that } \\
\text { identify a query protein as secretory or } \\
\text { nonsecretory by OET-KNN, predicts } \\
\text { possible signal peptide cleavage site by a } \\
\text { subsite-coupled discrimination algorithm, } \\
\text { and determines the final cleavage site by } \\
\text { fusing the global sequence alignment } \\
\text { outcome. }\end{array}$ & $\begin{array}{l}\text { http://www.csbio.sjtu.edu.cn/bioinf/Signal- } \\
\text { 3L/ }\end{array}$ \\
\hline MEMSAT-SVM & $\begin{array}{l}\text { Improved transmembrane protein topology } \\
\text { prediction using SVM. This method is } \\
\text { capable of differentiating signal peptides } \\
\text { from transmembrane helices. }\end{array}$ & $\begin{array}{l}\text { http://bioinf.cs.ucl.ac.uk/psipred/? } \\
\text { memsatsvm }=1\end{array}$ \\
\hline LipoP & $\begin{array}{l}\text { Predicts lipoproteins and discriminates } \\
\text { between lipoprotein signal peptides, other } \\
\text { signal peptides, and N-terminal membrane } \\
\text { helices in gram-negative bacteria. }\end{array}$ & http://www.cbs.dtu.dk/services/LipoP/ \\
\hline SecretomeP & $\begin{array}{l}\text { Produces ab initio predictions of } \\
\text { nonclassically secreted proteins. }\end{array}$ & http://www.cbs.dtu.dk/services/SecretomeP/ \\
\hline TatP & $\begin{array}{l}\text { Predicts the presence and localization of } \\
\text { twin-arginine signal peptide cleavage sites } \\
\text { in bacteria. }\end{array}$ & http://www.cbs.dtu.dk/services/TatP-1.0/ \\
\hline
\end{tabular}

\footnotetext{
${ }^{\text {a }}$ OET-KNN = optimized evidence-theoretic $\mathrm{K}$ nearest neighbor; $\mathrm{SVM}=$ support vector machine .
} 
cleavage site is recognized by a signal peptidase II (Zückert 2014).

The prediction of secretion and anchors signals are the main criteria for predicting a CSEP. After the first analysis, more than 1,000 predicted secreted proteins are usually retrieved for eukaryotes genomes but less than that for prokaryotes. Thereupon, an analytical pipeline can be used as a secondary criterion for prediction of subcellular localization, presence of domains, motifs, and structural properties, which can contribute to obtaining a refined identification of CSEP.

In general, pathogen effectors are structurally diverse and do not share conserved motifs or domains, with the exception of a few families of effector proteins (Dean 2011; Wawra et al. 2012). In oomycetes and fungi, the common motifs identified to date are RxLR, RxLx[EDQ], DEER, [KRHQSA][DENQ]EL, [Y/W]xC, and RSIVEQD (Sonah et al. 2016). The RxLR motif, for example, has been found in a large family of effectors in Phytophthora spp. and downy mildew pathogens (Tyler et al. 2013). The molecular function of RxLR-dEER motifs is still not fully understood and has been a subject for debate. Another example of oomycete effectors with conserved motif are the Crinkler (CRN) effectors of Phytophthora infestans, which share a conserved N-terminal LxLFLAK motif (Goss et al. 2013). Other oomycetes also present a complex pool of CRN effectors in their genomes; however, the LxLFAK motifs are not so conserved, with some minor amino acid variations (Stam et al. 2013). The RxLR and CRN motifs were also found in the Albugo candida repertoire of CSEP but in a lesser number in comparison with Phytophthora spp. (Links et al. 2011). Also in comparison with Phytophthora spp., a few CRN motif-CSEP were found in the genomes of recently sequenced Pythium spp.; however, no RxLR were predicted for these species (Adhikari et al. 2013).

Information about secondary and tertiary structure might contribute to evaluation of CSEP. Despite not having a universal conserved motif, some effectors share structural similarity; for example, AVR1-CO39 and AVR-Pia of Magnaporthe oryzae and AvrPiz-t of M. oryzae and ToxB of Pyrenophora tritici-repentis, which compose a family of effectors named Magnaporthe Avr and ToxB-like effectors (de Guillen et al. 2015). RxLR effectors also share abundant short $\alpha$-helices at the $\mathrm{C}$ terminus that might contribute to their functional adaptation (Boutemy et al. 2011).

Some effectors contain molecular mimics of plant subcellular localization signals, likely to translocate into various host subcellular compartments where target proteins are located (Deslandes and Rivas 2012). Various effectors have been localized to the plant cell membrane (Lewis et al. 2014), cytoplasm (Zhang et al. 2015), endoplasmic reticulum (Jing et al. 2016), Golgi network (Nomura et al. 2011), mitochondria (Block et al. 2010), chloroplast (Petre et al. 2016), and nucleus (Escoll et al. 2016). Nuclear effectors, for example, have nuclear localization signals generally rich in lysine and arginine, which are arranged as a single region or two basic regions internally to the effector sequence (Weinthal et al. 2011). Several tools are available for "ab initio" prediction of sorting signals and subcellular

Table 2. Common bioinformatics tools available for prediction of membrane anchors

\begin{tabular}{|c|c|c|}
\hline Tool & Description & Website \\
\hline TMHMM Server & $\begin{array}{l}\text { Predicts transmembrane (TM) protein } \\
\text { topology based on hidden Markov model } \\
\text { (HMM). }\end{array}$ & http://www.cbs.dtu.dk/services/TMHMM/ \\
\hline MEMSAT3 & $\begin{array}{l}\text { Predicts the secondary structure and topology } \\
\text { of all-helix integral membrane proteins } \\
\text { based on the recognition of topological } \\
\text { models. }\end{array}$ & $\begin{array}{l}\text { http://bioinf.cs.ucl.ac. } \\
\text { uk/software_downloads/memsat/ }\end{array}$ \\
\hline НMMTOP & $\begin{array}{l}\text { Automatic server for predicting TM helices } \\
\text { and topology of proteins. }\end{array}$ & http://www.enzim.hu/hmmtop/index.php \\
\hline TMpred & $\begin{array}{l}\text { Predicts membrane-spanning regions and } \\
\text { their orientation. The algorithm is based on } \\
\text { the statistical analysis of TMbase, a } \\
\text { database of naturally occurring TM } \\
\text { proteins. The prediction is made using a } \\
\text { combination of several weight-matrices for } \\
\text { scoring. }\end{array}$ & $\begin{array}{l}\text { http://www.ch.embnet. } \\
\text { org/software/TMPRED_form.html }\end{array}$ \\
\hline DAS & $\begin{array}{l}\text { Predicts TM } \alpha \text {-helices in prokaryotic } \\
\text { membrane proteins by a dense alignment } \\
\text { surface method. }\end{array}$ & http://www.sbc.su.se/ miklos/DAS/ \\
\hline TOPCONS & $\begin{array}{l}\text { Method for consensus prediction of } \\
\text { membrane protein topology and signal } \\
\text { peptides. }\end{array}$ & http://topcons.cbr.su.se/ \\
\hline PRED-TMR & $\begin{array}{l}\text { Predicts TM domains in proteins based on a } \\
\text { statistical analysis of the SwissProt } \\
\text { database. }\end{array}$ & http://athina.biol.uoa.gr/PRED-TMR/ \\
\hline TopPred 1.10 & $\begin{array}{l}\text { Predicts the topology of membrane proteins } \\
\text { on the basis of hydrophobicity analysis. }\end{array}$ & $\begin{array}{l}\text { http://mobyle.pasteur.fr/cgi-bin/portal.py? } \\
\text { \#forms::toppred }\end{array}$ \\
\hline ССТОР & Predicts TM topology. & http://cctop.enzim.ttk.mta.hu/ \\
\hline PRED-TMBB & $\begin{array}{l}\text { Method based on an HMM capable of } \\
\text { predicting TM } \beta \text {-strands of gram-negative } \\
\text { bacteria outer membrane proteins. }\end{array}$ & $\begin{array}{l}\text { http://bioinformatics.biol.uoa.gr/PRED- } \\
\text { TMBB/ }\end{array}$ \\
\hline GPI-SOM & $\begin{array}{l}\text { Identifies glycosylphosphatidylinositol (GPI) } \\
\text { anchor signals by a Kohonen self- } \\
\text { organizing map. }\end{array}$ & http://gpi.unibe.ch/ \\
\hline PRED-GPI & $\begin{array}{l}\text { Predicts GPI-anchored proteins based on a } \\
\text { support vector machine for the } \\
\text { discrimination of the anchoring signal, and } \\
\text { on a HMM for the prediction of the most } \\
\text { probable } \omega \text {-site. }\end{array}$ & $\begin{array}{l}\text { http://gpcr.biocomp.unibo.it/predgpi/pred. } \\
\text { htm }\end{array}$ \\
\hline Myristoylator & $\begin{array}{l}\text { Predicts N-terminal myristoylation by } \\
\text { ensemble of neural networks. }\end{array}$ & http://web.expasy.org/myristoylator/ \\
\hline
\end{tabular}


localization, which can provide valuable clues for determining the effectors' site of action inside plant cells. However, some methods require supplementary data input such as expression levels, gene ontology, and phylogenetic profiles for obtaining improved results (Table 3 ).

It is important to explore possible similarities of the predicted CSEP with other known effectors (Table 3). In this case, some criteria can be evaluated such as related effector domains, speciesspecific sequences, absence in nonpathogenic species, and gene localization in gene-sparse or repeat-rich regions (Sperschneider et al. 2014). The identification of structural features can be a suggestive approach for retaining CSEP from a repertoire of evaluated sequences.

\section{FUNCTIONAL CHARACTERIZATION OF CANDIDATE EFFECTORS}

Once identified by bioinformatics pipelines, CSEP can be experimentally characterized by several genetic, molecular, and cellular approaches, which are summarized in this section. Often, the first step is to obtain evidence that the computationally predicted genes encode proteins with relevant biological activity in planta. The most definitive evidence for effector function is to directly demonstrate that the encoded protein translocates from the pathogen to the apoplast or the interior of the plant cell. The classical approach is to use in situ hybridization with antibodies raised against the effector protein or an added epitope tag (Szurek et al. 2002). This approach has the added value of providing information about the CSEP's localization inside plant cells, which is important information for deducing the protein's function (Lo Presti et al. 2017; Mugford et al. 2016). However, the protocols for in situ hybridization are laborious and unsuitable for high throughput. Thus, this approach has been used for only a small number of effectors.

An emerging alternative is to create transgenic pathogen strains with tagged CSEP that can be tracked by microscopy or other straightforward assays. For example, Lo Presti and colleagues (2017) recently described an assay based on detection of biotinylation of effectors in planta. The assay requires a transgenic host plant expressing a bacterial biotin ligase (BirA) and a transgenic pathogen expressing a fusion of the effector gene to a short peptide (Avitag). If the effector protein enters the host cell, then the Avitag is biotinylated and easily detected via Western blotting. Another approach is to tag the effector with a fluorescent protein that can be visualized by confocal microscopy. This approach carries several technical challenges but was accomplished in fungi (Khang et al. 2010) and, recently, in an oomycete (Wang et al. 2017). These systems will be particularly useful for investigating the factors that control the translocation process, which is an area of substantial importance and intense interest, because inhibiting this process could restrict pathogen virulence activity.

Another classical, gold-standard approach for validating effector function is to knockout or knockdown the putative effector gene, and demonstrate that virulence or Avr phenotypes are compromised. Protocols for gene knockouts, based on homologous recombination (HR), have been well established for some bacterial (e.g., Pseudomonas syringae) and fungal (e.g., Magnaporthe, Verticillium, and Ustilago spp.) pathogens. Gene knockdown approaches, based on RNA interference, have also been used productively, particularly in pathogen species that are not amenable to classical HR-based gene knockouts. As in other areas of biology, genome editing systems (e.g., CRISPR/Cas9) are now proving broadly applicable. The best example is in oomycetes, which have been recalcitrant to many of the classical reverse genetic approaches. The CRISPR/Cas9 system works well for gene knockouts and for gene replacements in Phytophthora sojae and P. capsici, and efforts are underway to apply the system more broadly (Fang and Tyler 2016; Fang et al. 2017). Finally, approaches based on host-induced gene silencing are being explored to knockdown genes in fungi and oomycetes that are obligate and, therefore, difficult to transform (Govindarajulu et al. 2015).

Despite the utility of classical and new techniques for reverse genetics, alternative approaches for testing effector gene functions have been developed for several reasons. To begin with, several important plant-pathogenic taxa are obligate pathogens for which robust genetic transformation protocols are lacking (e.g., fungal rusts, powdery mildews, and oomycete downy mildews). Even when gene knockouts can be accomplished efficiently, the mutant might display a wild-type phenotype due to genetic redundancy, in which similar effector genes can perform the same function, or physiological compensation or buffering in the host, in which interference with a particular signaling sector could be masked by buffering from another sector (Hillmer et al. 2017; Tyler 2017) Finally, it is desirable in many cases to assess the

Table 3. Common bioinformatics tools available for prediction of subcellular localization, effectors motifs or domains, and genome architecture

\begin{tabular}{|c|c|c|}
\hline Tool & Description & Website or reference \\
\hline TargetP server & $\begin{array}{l}\text { Predicts the subcellular localization of } \\
\text { eukaryotic proteins. The localization } \\
\text { assignment is based on the predicted } \\
\text { presence of any transit, targeting, or } \\
\text { secretory signal peptide. }\end{array}$ & http://www.cbs.dtu.dk/services/TargetP/ \\
\hline PSORT programs & $\begin{array}{l}\text { Programs for subcellular localization } \\
\text { prediction and other datasets and resources } \\
\text { relevant to localization prediction. }\end{array}$ & http://www.psort.org/ \\
\hline PredictProtein & $\begin{array}{l}\text { Predicts subcellular localization and several } \\
\text { protein sequence analyses. }\end{array}$ & https://www.predictprotein.org/ \\
\hline LocTree & $\begin{array}{l}\text { Applies machine learning to predict the } \\
\text { native subcellular localization. }\end{array}$ & https://rostlab.org/services/loctree3/ \\
\hline InterProScan & $\begin{array}{l}\text { Scan sequences for matches against the } \\
\text { InterPro protein signature databases. }\end{array}$ & $\begin{array}{l}\text { https://www.ebi.ac. } \\
\text { uk/interpro/search/sequence-search }\end{array}$ \\
\hline Pfam & $\begin{array}{l}\text { Analyze protein sequence for matches } \\
\text { against a large collection of protein } \\
\text { families. }\end{array}$ & http://pfam.xfam.org/ \\
\hline Genome architecture & $\begin{array}{l}\text { Analysis of genome architecture has assisted } \\
\text { the mining for novel candidate effector } \\
\text { genes. }\end{array}$ & Saunders et al. 2014 \\
\hline LOCALIZER & $\begin{array}{l}\text { Analysis of predicted nuclear localization } \\
\text { signals, chloroplast transit peptides, and } \\
\text { mitochondrion transit peptides }\end{array}$ & http://localizer.csiro.au/ \\
\hline
\end{tabular}


effects of a single effector gene in plant cells, independent of effects of dozens or hundreds of other virulence factors that are deployed by the pathogen during a normal infection.

For these reasons, a number of approaches have been developed to express effector genes in planta, one at a time. One straightforward approach is to create transgenic plants that are stably transformed with the effector genen pioneered by Hauck et al. (2003) (Fig. 2). The first step is cloning the coding sequence of the CSEP into an appropriate plasmid vector for expression in plants. The coding region typically encodes the presumptive processed form of the protein (e.g., beginning at the computationally cleavage site of the SP). A fluorescent or affinity tag can be added to the $\mathrm{N}$ or $\mathrm{C}$ terminal for subcellular localization by confocal microscopy or immunodetection. Expression of the effector gene can be controlled by a constitutive or inducible plant promoter. The transgene can then be transformed into the appropriate plant. This step can be easily accomplished in Arabidopsis by floral dipping (Fig. 3). Other plants require more time-consuming transformation approaches.

Arabidopsis lines, overexpressing pathogen effectors, have provided a wealth of knowledge on effector biology. Early work investigated bacterial effectors (Munkvold and Martin 2009) and the same techniques are applicable to fungal and oomycete proteins. However, there are drawbacks to this approach. First, the protein is most likely present at higher levels from the transgene than if it were delivered by the pathogen. This overabundance could lead to hypomorphic or neomorphic phenotypes in the transgenic plant, although this generally does not seem to be the case. Another drawback is that transformation remains laborious for many plant species; thus, the throughput can be low. Arabidopsis is frequently used to investigate functions of effectors from pathogens that are not natural pathogens of Arabidopsis, but one must always be aware of the possibility of different responses in a nonhost plant species.

For these reasons, bacteria have been adopted as surrogates to deliver effectors to plant cells. Agroinfiltration-mediated transient transformation (ATTA) (Fig. 2) is one of the simplest systems used to evaluate effector function in plants (Sparkes et al. 2006). Typically, 4- to 5-week-old Nicotiana benthamiana or Solanum plants are used for agroinfiltration. The efficiency of the expression can be influenced by the strain of agrobacterium used; in this case, strain GV3101 is suited for $N$. benthamiana and strain AGL1 for Solanum plants (Du and Vleeshouwers 2014).

\section{DEVELOPMENT OF GENE CONSTRUCTIONS}

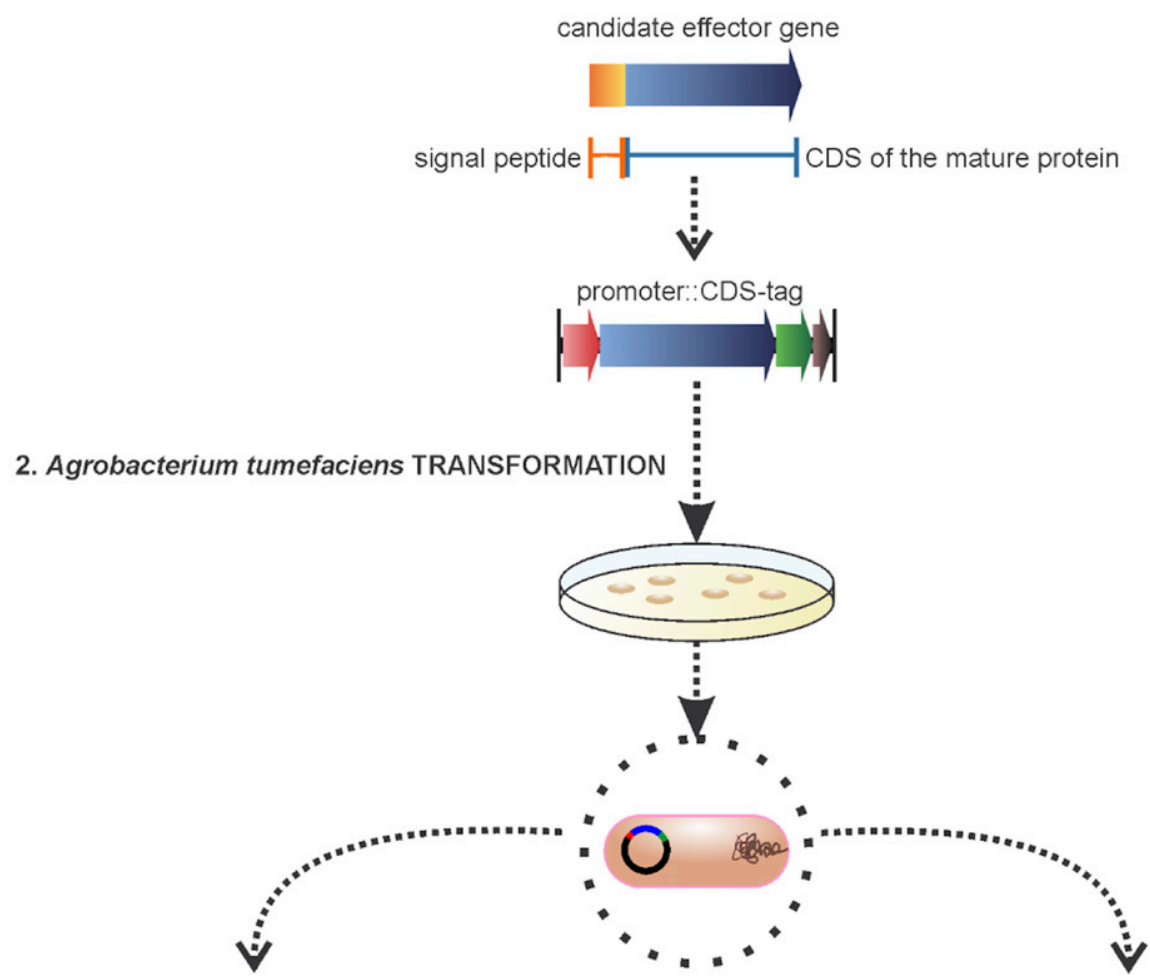

3. TRANSIENT GENE EXPRESSION ASSAY

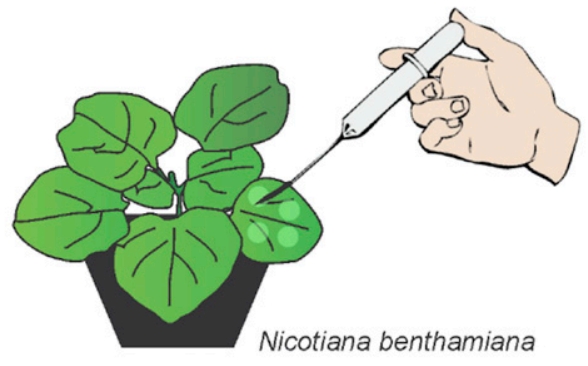

agroinfiltration method
4. Arabidopsis thaliana TRANSFORMATION

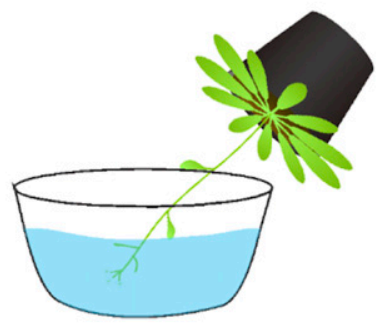

floral dip method

Fig. 2. General strategies for characterization of candidate-secreted effector proteins by transient expression in Nicotiana benthamiana by agroinfiltration and transformation of Arabidopsis thaliana by the floral dip method. 
Inoculations of Agrobacterium suspensions are carried out by syringe infiltration, in which pressure is exerted with the tip of the syringe (without a needle) against the abaxial side of the leaf. During this process it is possible to observe the suspension as it spreads into the leaf. In order to obtain successful results, young and well-developed leaves are typically used. It is also important to include negative and positive controls in the inoculated leaf (Fig. 3). A suspension of transformed Agrobacterium with an empty vector is well suited as a negative control and a construct containing an HR-inducing gene as positive control. In this case, the $P$. infestans INF1 elicitor is commonly used-an extracellular protein that induces cell death (Wang et al. 2011). Responses can be observed approximately 2 to 3 days after inoculation. Suppression of this cell death is a simple and efficient way to visualize the function of an effector.

A major limitation of ATTA is that it does not work robustly in many plants, including Arabidopsis. Thus, Pseudomonas spp. have been utilized as a surrogate for delivery of heterologous effectors by their type III secretion system (T3SS). Like ATTA, this approach can be used to investigate single genes or can be scaled up to screen large libraries of CSEP for induction or suppression of immunity (Fabro et al. 2011). Pseudomonas spp. are easily transformed with a plasmid containing a gene encoding the protein of interest fused to a leader that directs the protein to the secretory apparatus (Sohn et al. 2007). The bacterial strain should be chosen carefully: it should not cause plant disease or a strong resistance directly and should be amenable to transformation. One of the most commonly used strains is Pseudomonas fluorescens, which is a nonpathogenic soildwelling strain. This strain does not contain an endogenous T3SS or type III effectors of its own; thus, it does not cause disease symptoms in many hosts. However, researchers have created a transgenic strain that contains genes for a T3SS from $P$. syringae (Thomas et al. 2009). Thus, one can transform this strain with a plasmid containing the effector gene of interest. The encoded protein will be the only one translocated into host cells. This strain is called an effector-to-host analyzer (EtHAn) (Thomas et al. 2009). Another useful strain is a derivative of $P$. syringae DC3000 called D28E, in which almost all of the genes encoding the type III effector have been deleted (Cunnac et al. 2011). This strain could be particularly useful for reconstruction experiments and assaying the effects of two or more effectors delivered together. This could reveal emergent properties of multiple effectors that would not be apparent in one-effector-at-a-time assays.

Regardless of how an effector protein is delivered to plant cells, a variety of functional assays can be employed to assess the effector's effect on plant cell functionality. The simplest assay is for induction of HR-like cell death, indicative of toxin or Avr activity (Whisson et al. 2007). A complementary assay is to test whether the transgene could suppress an HR that is triggered by a different elicitor, as described above. Biological significance can be further demonstrated through observation of pathogen growth and reproduction. For bacteria, this can be accomplished by observation of disease symptoms, or more quantitatively by direct measurement of bacterial titer in planta. Fungal or oomycete virulence can be assessed in a variety of ways, including direct observation of external pathogen structures (e.g., sporangiophores or conidiophores). Pathogen DNA quantification by polymerase chain reaction is growing in prevalence (Anderson and McDowell 2015).

Microscopy illuminates major cellular events during pathogen infection, and can give insight into immune responses. The mechanisms behind differences in pathogen burden can be observed directly. Cytological studies can be facilitated by simple staining techniques. Aniline blue stains callose, and highlights physical defense response to pathogen attack. Trypan blue stains polysaccharides in the oomycete cell walls as well as dead plant tissue, revealing hypersensitive response of ETI, as well as fungal or oomycete vegetative structures. Diaminobenzedene stains in the presence of reactive oxygen species, identifying chemical response to pathogen infection.

RNA sequencing allows for exquisite resolution of messenger RNA profiles in infected tissue, including pathogen transcripts (Asai et al. 2014). Researchers have identified highly expressed effectors through this method, some trying to isolate core effectors that the pathogen requires for virulence (Wang et al. 2011). This approach can also be used for insight into an individual effector's mode of action.

Once inside the plant cell, effectors move to their target, often by utilizing host trafficking machinery. Transgenic plants expressing fluorescently labeled proteins have elucidated key interactions in infected plant cells (Caillaud et al. 2014; Takemoto et al. 2003) Plants expressing these constructs reveal the

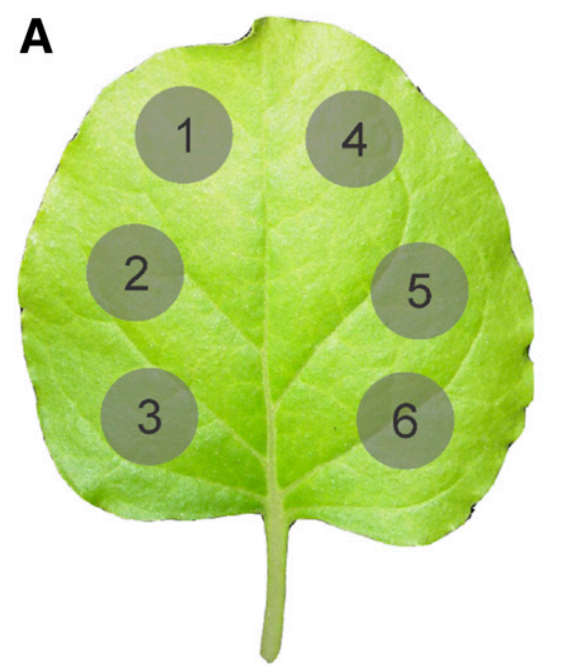

B

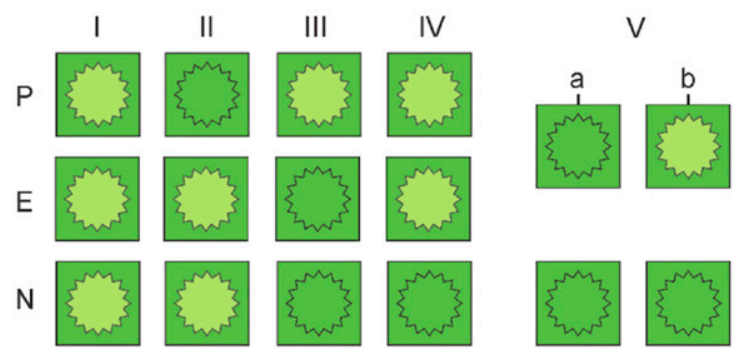

Fig. 3. A, Strategy for characterization of effectors in Nicotiana benthamiana leaves: $1=$ negative control (buffer), $2=$ negative control (agrobacterium containing a vector without gene insert), $3=$ effector candidate, $4=$ positive control (homologous recombination $[\mathrm{HR}]$-inducing gene), $5=$ coinfiltration $(\mathrm{HR}$ inducing gene with effector candidate), and $6=$ coinfiltration (effector candidate with silencing inhibitor; e.g., P19). B, Responses of different plant genotypes to a hypothetical effector protein: $\mathrm{I}=$ nonspecific response to negative control, II = nonspecific response and failed response to positive control, III = no response to effector, $\mathrm{IV}=$ effector with elicitor response, $\mathrm{V}=$ coinfiltration (HR-inducing gene with effector candidate), Va $=$ effector with suppressive activity over $\mathrm{HR}$-inducing gene, and $\mathrm{Vb}=$ effector with no activity over HR-inducing gene. 
subcellular motion of effectors in vivo (Caillaud et al. 2012). Effector proteins have been observed interacting with nuclear pore proteins and transcriptional machinery (Szurek et al. 2001), perhaps presaging roles in reprogramming of host gene expression.

\section{IDENTIFICATION OF EFFECTOR TARGETS}

Perhaps the most important aspect of functional characterization is to find the exact molecular target or targets of the CSEP of interest. This aspect is also very challenging, because the sequences of CSEP typically provide few or no clues about their molecular function. Thus, the first step often involves unbiased screens for plant proteins that interact directly with the effector. These are candidate targets for effector manipulation. The yeast two-hybrid screen is often used for this purpose (Deslandes et al. 2003; Guo et al. 2016) and has been applied at genomic scales (Mukhtar et al. 2011; Wessling et al. 2014). Another approach is to use an overexpressed, tagged effector to pull down interacting proteins, and identify these by mass spectrometry (Fu et al. 2007).

Both of these approaches have well-described caveats, most prominent of which is a tendency to report protein interactions with questionable relevance. Thus, the initial screen is typically only the beginning of a long process to validate that the proteinprotein interaction is biologically relevant to the interaction between the plant and the pathogen. This validation effort most commonly follows a path that is defined by questions about the putative interacting proteins.

\section{Can the protein-protein interaction be reproduced using different assays?}

This is typically addressed by a combination of directed yeast-two hybrid screens, coimmunoprepitation (co-IP) assays in vivo or in vitro, and bimolecular fluorescence (BiFC) complementation. Each of these assays has particular strengths and weaknesses, and tend to be complementary to each other. For example, in vivo co-IP assays report on the situation inside plant cells but can report either direct or indirect interactions between the proteins in question. In contrast, yeast two-hybrid assays and in vitro co-IP are simple and typically report direct protein-protein interactions but don't necessarily report the situation inside plant cells. BiFC reports the interaction inside plant cells and can provide information about the subcellular localization of the protein interaction but is prone to falsepositive results.

\section{Do the effector and its target localize to the same subcellular address?}

This can be examined with confocal microscopy using individual tagged proteins with fluorescent tags, BiFC, or immunolocalization. The first approach is most commonly used and provides the advantage of direct observation in living cells. However, overexpression can affect protein localization. Another potential pitfall is that protein localization might be different in infected and uninfected cells.

\section{Does the phenotype of a knockout or knockdown of the target gene phenocopy a transgenic plant expression the effector?}

This sort of result is often taken as very important validation of a candidate protein-protein interaction. False-negative results can arise if the knockout phenotype of the putative plant target is masked by functional redundancy from related genes or buffering from compensatory pathways. As with any genetic experiment, the outcome can be affected by the phenotypic assays that one employs. An effect on growth of the relevant pathogen is the gold standard but other, more subtle phenotypes can provide a sound basis for supporting the biological relevance of the interaction.

Although laborious, this process for identifying effector targets has been extremely productive for understanding the molecular basis of interaction between plants and many important lineages of pathogens. In particular, effectors have been uncannily productive in leading us to plant proteins or pathways for which the importance was previously unsuspected (Pais et al. 2013). In our view, the molecular plant-microbe interaction field has only scratched the surface of what can be revealed about plant regulatory networks using effector-guided studies.

\section{EFFECTOROMICS}

Another area in which we can be productively guided by effectors is in the search for new sources of host genetic resistance. As mentioned at the beginning of this article, we now know that, in most cases, classical gene-for-gene resistance involves direct or indirect interaction between a pathogen effector protein and a plant disease resistance gene that encodes an immune surveillance protein. The surveillance protein typically belongs to the nucleotidebinding, leucine-rich repeat protein superfamily. Thus, it follows logically that one could use effectors directly as probes for cognate resistance genes. The approach combines functional screening of effectors by transient expression in plant germplasm with modern resistance breeding strategies.

We refer to this approach as "effectoromics" following Vleeshouwers and colleagues (2011a,b), who pioneered this approach for late blight of potato, using Phytophthora infestans effectors as probes (Hein et al. 2009). The general approach is to create a library of predicted RXLR effector genes in a plasmid vector that could be used for Agrobacterium-mediated transient transformation; this particular vector contained the effector transgene incorporated within a Potato virus $X(\mathrm{PVX})$ replicon that could spread beyond the original infiltration site, thereby "amplifying" transformation and expression of the effector transgene. Agrobacterium strains, each containing one RXLR effector gene, were injected into leaves of wild relatives of tomato and potato. The leaves were then screened visually for a macroscopic cell death lesion, indicative of an HR triggered by a resistance gene that recognized that particular effector. Vleeshouwers et al. (2008) used a repertoire of 54 predicted $P$. infestans effectors to discover candidate $R$ genes in Solanum spp. (Vleeshouwers et al. 2008). The main steps for this effectoromics analysis are summarized in Figure 3.

What are the advantages of this approach, compared with classical, pathogen-based screens for new $R$ genes? To begin with, effector-based screens often provide higher throughput and a more straightforward phenotype than pathogen-based screens. Thus, the screening process can be streamlined. This approach can also eliminate redundancy in sources of resistance by delineating sources that recognize the same effector. Effector-based screens can also be combined with functional genomics that enables identification of effectors that are important for virulence and monomorphic within the species. $R$ genes that recognize essential effectors should be broadly effective and robust to pathogen coevolution. Effector-based screening can be used to identify new $R$ genes within and outside of the pathogen's host. Finally, knowledge of the effector that an $R$ gene recognizes can enable strategies to quickly detect resistance-breaking strains that contain mutations in that effector gene.

One major challenge of effectoromics is that it requires functional assays based on transient expression; for example, Agrobacteriumbased methods such as agroinfiltration and PVX agroinfection. Unfortunately, Agrobacterium-based methodologies are effective in Nicotianae and Solanum plants but are not yet efficient for most other important crop plants (Wroblewski et al. 2005). For 
this reason, systems based on delivery through the T3SS of Pseudomonas spp. provide a potentially viable option. With this approach, the major factors are to find a strain that can multiply in the germplasm of interest without provoking an HR or severe disease symptoms that could be mistaken for an HR. Moreover, the strain must contain a functional T3SS and must be transformable with standard bacterial plasmid vectors. The EtHAn strain of Pseudomonas fluorescens described above has been utilized for effectoromics in wheat (Upadhyaya et al. 2014a,b) and soybean (McDowell lab, unpublished). In the case of soybean, the replication of EtHAn in planta could be enhanced by coinfiltrating with a strain of $P$. syringae pv. glycinea that is virulent on soybean. This "helper strain" boosted multiplication of EtHAn by several fold, enabling a stronger HR response (McDowell lab, unpublished). We hypothesize that the $P$. syringae pv. glycinea strain is suppressing PTI and thereby enabling more aggressive growth of EtHAn. This helper-strain-based approach could be extended to other host species by including bacterial strains that are virulent on that particular host. However, controls must be included to ensure that the helper strain is not provoking any cultivar-specific HR in the germplasm that is being screened. Indeed, we discovered a putative $R$ gene against $P$. syringae pv. glycinea in several lines of Glycine soja, a wild relative of cultivated soybean (McDowell lab, unpublished).

Another logistical challenge of effectoromics is that the effort for a comprehensive screen of hundreds of candidate effectors, on dozens of plant cultivars, is typically prohibitive. How to prioritize which effectors and plant lines to screen? Effectors could be prioritized using genomic and transcriptomic data. Considering the ever-decreasing cost of sequencing, it is possible to obtain draft genomes or to use sequence capture methods to survey allelic diversity and gene expression across multiple isolates. These data could be used to eliminate genes that are not expressed, and to prioritize genes that are expressed at high levels, early in the infection process. Genomic data could be used to identify genes with signatures of diversifying selection that are often indicative of Avr function. On the other hand, one might choose to prioritize effector genes with low sequence diversity between strains, because an $R$ gene recognizing a conserved effector might have broad utility against most or all field isolates of the pathogen. Sequence conservation might also imply functional importance that could be tested by reverse genetics (e.g., CRISR/Cas9; see above). Indeed, an ideal screen would identify effectors that the pathogen could not delete without loss of virulence; $R$ genes against such effectors could be robust to pathogen coevolution (e.g., mutation or silencing of the effector).

One caveat of effectoromics is the possibility of false-positive hits from the screen. A cell death response might be triggered by toxin activity of the effectors that does not involve a corresponding $R$ gene in the host. It is also possible that $R$ genes discovered through bacterial delivery might be ineffective in an interaction with the actual pathogen, perhaps due to suppression by other effectors that the pathogen produces. For these reasons, it is prudent to combine effectoromics with classical, pathogen-based screens when possible. For example, host germplasm could be screened with pathogen isolates that have broken $R$ genes that were previously deployed in the crop. This would allow prioritization of cultivars that contain potentially novel $R$ gene loci or alleles. Moreover, one can then use classical genetics to rule out the above false positives: One can track the segregation of effector response and pathogen recognition in progeny (e.g., F3 families or recombinant inbred lines) from a cross between the resistant and susceptible lines. To make this point clear: effector recognition and pathogen resistance should be considered as separate traits, which might not necessarily be conditioned by the same gene. Progeny testing can be used to prioritize cultivars in which recognition of the effector and resistance to the pathogen display simple inheritance patterns and map to the same locus. The mapping population can then be further exploited to fine map the resistance gene and develop molecular markers that can be used in breeding programs.

Effectoromics is a new and rapidly developing area that holds great potential for many disease problems (Du and Vleeshouwers 2014; Vleeshouwers and Oliver 2014). We look forward to broader application of this approach and resultant emergence of best practices.

\section{Perspectives and future directions.}

Over recent decades, much information has been gathered regarding the biology of effectors and their importance in plantpathogen interactions (Hogenhout et al. 2009). Much of this work was accomplished through focusing on a relatively small collection of pathosystems that were distinguished by experimental convenience and, in some cases, by substantial economic impact of the disease. This focus fueled development of techniques for identifying effector genes and delineating their functions and targets that, in turn, illuminated many new mechanistic aspects of molecular plant-microbe interactions. The molecular plant-microbe interaction field is now in a strong position to develop these techniques further and apply them to a broader collection of pathosystems that encompass interesting biological diversity as well as disease problems that affect large- and small-scale production system for food, feed, and fiber. Such research will become even more accessible and efficient in the near term as the cost of sequencing continues to drop, bioinformatic pipelines continue to gain predictive power, and genome modification techniques are optimized for diverse plants and microbes. In addition to illuminating the diversity and convergences under which plants and pathogens interact, new doors are now broadly open toward the use of effectoromics, host-induced gene silencing, and modification of effector target genes as new tools in integrated programs to reduce the impact of plant diseases (Michelmore et al. 2017).

\section{ACKNOWLEDGMENTS}

Support in the Machado lab was provided by Fundação de Amparo a Pesquisa no Estado de São Paulo (FAPESP) (grant number 2014/50880-0 and 2015/14498-6) and the Conselho Nacional de Ciência e Tecnologia (grant numbers 573848/ 2008-4, 465440/2014-2, and 445390/2014-0). Support in the McDowell lab was provided by the United States National Science Foundation Grant IOS-1353366 and by Agriculture and Food Research Initiative Competitive Grant number 224426 from the United States Department of Agriculture-National Institute of Food and Agriculture.

\section{LITERATURE CITED}

Adhikari, B. N., Hamilton, J. P., Zerillo, M. M., Tisserat, N., Levesque, C. A., and Buell, C. R. 2013. Comparative genomics reveals insight into virulence strategies of plant pathogenic oomycetes. PLoS One 8:e75072.

Anderson, R. G., Deb, D., Fedkenheuer, K., and McDowell, J. M. 2015. Recent progress in RXLR effector research. Mol. Plant-Microbe Interact. 28:1063-1072.

Anderson, R. G., and McDowell, J. M. 2015. A PCR assay for the quantification of growth of the oomycete pathogen Hyaloperonospora arabidopsidis in Arabidopsis thaliana. Mol. Plant Pathol. 16:893-898.

Asai, S., Rallapalli, G., Piquerez, S. J., Caillaud, M. C., Furzer, O. J., Ishaque, N., Wirthmueller, L., Fabro, G., Shirasu, K., and Jones, J. D. 2014. Expression profiling during Arabidopsis/downy mildew interaction reveals a highly-expressed effector that attenuates responses to salicylic acid. PLoS Pathog. 10:e1004443.

Bendtsen, J. D., Jensen, L. J., Blom, N., von Heijne, G., and Brunak, S. 2004. Feature-based prediction of non-classical and leaderless protein secretion. Protein Eng. Des. Sel. 17:349-356.

Bendtsen, J. D., Kimer, L., Fausbøll, A., and Brunak, S. 2005. Non-classical protein secretion in bacteria. BMC Microbiol. 5:58.

Bent, A. F., and Mackey, D. 2007. Elicitors, effectors, and $R$ genes: The new paradigm and a lifetime supply of questions. Annu. Rev. Plant Pathol. 45 $399-436$. 
Bigeard, J., Colcombet, J., and Hirt, H. 2015. Signaling mechanisms in pattern-triggered immunity (PTI). Mol. Plant 8:521-539.

Block, A., Guo, M., Li, G., Elowsky, C., Clemente, T. E., and Alfano, J. R. 2010. The Pseudomonas syringae type III effector HopG1 targets mitochondria, alters plant development and suppresses plant innate immunity. Cell. Microbiol. 12:318-330.

Bos, J. I. B., Armstrong, M. R., Gilroy, E. M., Boevink, P. C., Hein, I., Taylor, R. M., Zhendong, T., Engelhardt, S., Vetukuri, R. R., Harrower, B., Dixelius, C., Bryan, G., Sadanandom, A., Whisson, S. C., Kamoun, S., and Birch, P. R. J. 2010. Phytophthora infestans effector AVR3a is essential for virulence and manipulates plant immunity by stabilizing host E3 ligase CMPG1. Proc. Natl. Acad. Sci. USA 107:9909-9914.

Boutemy, L. S., King, S. R., Win, J., Hughes, R. K., Clarke, T. A., Blumenschein, T. M., Kamoun, S., and Banfield, M. J. 2011. Structures of Phytophthora RXLR effector proteins: A conserved but adaptable fold underpins functional diversity. J. Biol. Chem. 286:35834-35842.

Caillaud, M. C., Piquerez, S. J., Fabro, G., Steinbrenner, J., Ishaque, N., Beynon, J., and Jones, J. D. 2012. Subcellular localization of the Hpa RxLR effector repertoire identifies a tonoplast-associated protein HaRxL17 that confers enhanced plant susceptibility. Plant J. 69:252-265.

Caillaud, M.-C., Wirthmueller, L., Sklenar, J., Findlay, K., Piquerez, S. J., Jones, A. M., Robatzek, S., Jones, J. D., and Faulkner, C. 2014. The plasmodesmal protein PDLP1 localises to haustoria-associated membranes during downy mildew infection and regulates callose deposition. PLoS Pathog. 10:e1004496.

Cambronne, E. D., and Roy, C. R. 2006. Recognition and delivery of effector proteins into eukaryotic cells by bacterial secretion systems. Traffic (Oxford, U. K.) 7:929-939.

Chrispeels, M. J. 1991. Sorting of proteins in the secretory system. Annu. Rev. Plant Physiol. 42:21-53.

Cui, H., Tsuda, K., and Parker, J. E. 2015. Effector-triggered immunity: From pathogen perception to robust defense. Annu. Rev. Plant Biol. 66: 487-511.

Cui, H., Wang, Y., Xue, L., Chu, J., Yan, C., Fun, J., Chen, M., Innes, R. W., and Zhou, J. M. 2010. Pseudomonas syringae effector protein AvrB perturbs Arabidopsis hormone by activating MAP kinase 4. Cell Host Microbe 7:164-175.

Cunnac, S., Chakravarthy, S., Kvitko, B. H., Russell, A. B., Martin, G. B., and Collmer, A. 2011. Genetic disassembly and combinatorial reassembly identify a minimal functional repertoire of type III effectors in Pseudomonas syringae. Proc. Natl. Acad. Sci. U.S.A. 108:2975-2980.

Dalio, R. J. D., Fleischmann, F., Chambery, A., Eichmann, R., Massola, N. S., Jr., Pascholati, S. F., and Osswald, W. 2017. Immunodepletion of $\alpha$-plurivorin effector leads to loss of virulence of Phytophthora plurivora towards Fagus sylvatica. For. Pathol. 47:e12362.

de Guillen, K., Ortiz-Vallejo, D., Gracy, J., Fournier, E., Kroj, T., and Padilla, A. 2015. Structure analysis uncovers a highly diverse but structurally conserved effector family in phytopathogenic fungi. PLoS Pathog. 11:e1005228.

Dean, P. 2011. Functional domains and motifs of bacterial type III effector proteins and their roles in infection. FEMS Microbiol. Rev. 35:1100-1125.

Deslandes, L., Olivier, J., Peeters, N., Feng, D. X., Khounlotham, M., Boucher, C., Somssich, I., Genin, S., and Marco, Y. 2003. Physical interaction between RRS1-R, a protein conferring resistance to bacterial wilt, and PopP2, a type III effector targeted to the plant nucleus. Proc. Natl. Acad. Sci. USA 100:8024-8029.

Deslandes, L., and Rivas, S. 2012. Catch me if you can: Bacterial effectors and plant targets. Trends Plant Sci. 17:644-655.

de Wit, P. J. G. M. 2016. Cladosporium fulvum effectors: Weapons in the arms race with tomato. Annu. Rev. Plant Pathol. 54:1-23.

Du, J., and Vleeshouwers, G. A. A. 2014. The do's and don'ts of effectoromics. Pages 257-268 in: Plant-Pathogen Interactions Methods and Protocols, 2nd ed. P. Birch, J. T. Jones, and J. I. B. Bos, eds. Humana Press, New York.

Escoll, P., Mondino, S., Rolando, M., and Buchrieser, C. 2016. Targeting of host organelles by pathogenic bacteria: A sophisticated subversion strategy. Natl. Rev. 14:5-19.

Fabro, G., Steinbrenner, J., Coates, M., Ishaque, N., Baxter, L., Studholme, D. J., Körner, E., Allen, R. L., Piquerez, S. J., and Rougon-Cardoso, A. 2011. Multiple candidate effectors from the oomycete pathogen Hyaloperonospora arabidopsidis suppress host plant immunity. PLoS Pathog. 7:e1002348.

Fang, Y., and Tyler, B. M. 2016. Efficient disruption and replacement of an effector gene in the oomycete Phytophthora sojae using CRISPR/Cas9. Mol. Plant Pathol. 17:127-139.

Fang, Y., Cui, L., Gu, B., Arredondo, F., and Tyler, B. M. 2017. Efficient genome editing in the oomycete Phytophthora sojae using CRISPR/ Cas9. Unit 21A in: Current Protocols in Microbiology. John Wiley \& Sons, Inc., Hoboken, NJ, U.S.A. doi:10.1002/cpmc.25
Flor, H. H. 1956. The complementary genic systems in flax and flax rust. Adv. Genet. 8:29-54.

Flor, H. H. 1971. Current status of the gene-for-gene concept. Annu. Rev. Plant Pathol. 9:275-296.

Fu, Z. Q., Guo, M., Jeong, B.-r., Tian, F., Elthon, T. E., Cerny, R. L., Staiger, D., and Alfano, J. R. 2007. A type III effector ADP-ribosylates RNAbinding proteins and quells plant immunity. Nature 447:284-288.

Goss, E. M., Press, C. M., and Grünwald, N. J. 2013. Evolution of RxLRclass effectors in the oomycete plant pathogen Phytophthora ramorum. PLoS One 8:pe79347.

Govindarajulu, M., Epstein, L., Wroblewski, T., and Michelmore, R. W. 2015. Host-induced gene silencing inhibits the biotrophic pathogen causing downy mildew of lettuce. Plant Biotechnol. J. 13:875-883.

Guo, M., Kim, P., Li, G., Elowsky, C. G., and Alfano, J. R. 2016. A bacterial effector co-opts calmodulin to target the plant microtubule network. Cell Host Microbe 19:67-78.

Hann, D., and Boller, T. 2012. Microbial effectors and their role in plant defense suppression. Pages 33-54 in: Effectors in Plant-Microbe Interactions, 1st ed. F. Matin and S. Kamoun, ed. John Wiley \& Sons, Chichester, UK.

Hauck, P., Thilmony, R., and He, S. Y. 2003. A Pseudomonas syringae type III effector suppresses cell wall-based extracellular defense in susceptible Arabidopsis plants. Proc. Natl. Acad. Sci. USA 100:8577-8582.

Hein, I., Gilroy, E. M., Armstrong, M. R., and Birch, P. R. J. 2009. The zigzag-zig in oomycete-plant interactions. Mol. Plant Pathol. 10:547-562.

Hillmer, R. A., Tsuda, K., Rallapalli, G., Asai, S., Truman, W., Papke, M. D., Sakakibara, H., Jones, J. D., Myers, C. L., and Katagiri, F. 2017 The highly buffered Arabidopsis immune signaling network conceals the functions of its components. PLoS Genet. 13:e1006639.

Hogenhout, S. A., Van der Hoorn, R. A., Terauchi, R., and Kamoun, S. 2009. Emerging concepts in effector biology of plant-associated organisms. Mol. Plant-Microbe Interact 22:115-122.

Jing, M., Guo, B., Li, H., Yang, B., Wang, H., Kong, G., Zhao, Y., Xu, H., Wang, Y., Ye, W., Dong, S., Qiao, Y., Tyler, B. M., Ma, W., and Wang, Y. 2016. A Phytophthora sojae effector suppresses endoplasmic reticulum stress-mediated immunity by stabilizing plant binding immunoglobulin proteins. Nat. Commun. 7:Article 11685.

Jones, J. D., and Dangl, J. L. 2006. The plant immune system. Nature 444: 323-329.

Kale, S. D., and Tyler, B. M. 2011. Entry of oomycete and fungal effectors into plant and animal host cells. Cell. Microbiol. 13:1839-1848.

Karasov, T. L., Horton, M. W., and Bergelson, J. 2014. Genomic variability as a driver of plant-pathogen coevolution? Curr. Opin. Plant Biol. 18: 24-30.

Khang, C. H., Berruyer, R., Giraldo, M. C., Kankanala, P., Park, S. Y., Czymmek, K., Kang, S., and Valent, B. 2010. Translocation of Magnaporthe oryzae effectors into rice cells and their subsequent cellto-cell movement. Plant Cell 22:1388-1403.

Kim, M. G., da Cunha, L., McFall, A. J., Belkhadir, Y., DebRoy, S., Dangl, J. L., and Mackey, D. 2005. Two Pseudomonas syringae type III effectors inhibit RIN4-regulated basal defense in Arabidopsis. Cell 121: 749-759.

Lee, D., Bourdais, G., Yu, G., Robatzek, S., and Coaker, G. 2015. Phosphorylation of the plant immune regulator RPM1-INTERACTING PROTEIN4 enhances plant plasma membrane H+-ATPase activity and inhibits flagellin-triggered immune responses in Arabidopsis. Plant Cell 27:2042-2056.

Lewis, J. D., Wilton, M., Mott, G. A., Lu, W., Hassan, J. A., Guttman, D. S., and Desveaux, D. 2014. Immunomodulation by the Pseudomonas syringae HopZ type III effector family in Arabidopsis. PLoS One 9: e116152.

Links, M. G., Holub, E., Jiang, R. H., Sharpe, A. G., Hegedus, D., Beynon, E., Sillito, D., Clarke, W. E., Uzuhashi, S., and Borhan, M. H. 2011. De novo sequence assembly of Albugo candida reveals a small genome relative to other biotrophic oomycetes. BMC Genomics 12:503-533.

Liu, J., Elmore, J. M., Lin, Z. J., and Coaker, G. 2011. A receptor-like cytoplasmic kinase phosphorylates the host target RIN4, leading to the activation of an innate immune receptor. Cell Host Microbe 9: 137-146.

Liu, T., Song, T., Zhang, X., Yuan, H., Su, L., Li, W., Xu, J., Liu, S., Chen, L., Chen, T., Zhang, M., Gu, L., Zhang, B., and Dou, D. 2014. Unconventionally secreted effectors of two filamentous pathogens target plant salicylate biosynthesis. Nat. Commun. 5:4686.

Lo Presti, L., Zechmann, B., Kumlehn, J., Liang, L., Lanver, D., Tanaka, S., Bock, R., and Kahmann, R. 2017. An assay for entry of secreted fungal effectors into plant cells. New Phytol. 213:956-964.

Ma, L. S., Hachani, A., Lin, J. S., Filloux, A., and Lai, E. M. 2014. Agrobacterium tumefaciens deploys a superfamily of type VI secretion 
DNase effectors as weapons for interbacterial competition in planta. Cell Host Microbe 16:94-104.

Macho, A. P., and Zipfel, C. 2014. Plant PRRs and the activation of innate immune signaling. Mol. Cell 54:263-272.

Marín, M., Uversky, V. N., and Ott, T. 2013. Intrinsic disorder in pathogen effectors: Protein flexibility as an evolutionary hallmark in a molecular arms race. Plant Cell 25:3153-3157.

Maurer-Stroh, S., Eisenhaber, B., and Eisenhaber, F. 2002. N-terminal $\mathrm{N}$-myristoylation of proteins: Refinement of the sequence motif and its taxon-specific differences. J. Mol. Biol. 317:523-540.

Mayor, S., and Riezman, H. 2004. Sorting GPI-anchored proteins. Nat. Rev. Mol. Cell Biol. 5:110-120.

McCann, H. C., and Guttman, D. S. 2008. Evolution of the type III secretion system and its effectors in plant-microbe interactions. New Phytol. 177:33-47.

Michelmore, R., Coaker, G., Bart, R., Beattie, G., Bent, A., Bruce, T. Cameron, D., Dangl, J., Dinesh-Kumar, S., Edwards, R., Eves-van den Akker, S., Gassmann, W., Greenberg, J. T., Hanley-Bowdoin, L., Harrison, R. J., Harvey, J., He, P., Huffaker, A., Hulbert, S., Innes, R., Jones, J. D. G., Kaloshian, I., Kamoun, S., Katagiri, F., Leach, J., Ma, W., McDowell, J., Medford, J., Meyers, B., Nelson, R., Oliver, R., Qi, Y., Saunders, D., Shaw, M., Smart, C., Subudhi, P., Torrance, L., Tyler, B., Valent, B., and Walsh, J. 2017. Foundational and translational research opportunities to improve plant health. Mol. Plant-Microbe Interact 30:515-516.

Mugford, S. T., Barclay, E., Drurey, C., Findlay, K. C., and Hogenhout S. A. 2016. An immuno-suppressive aphid saliva protein is delivered into the cytosol of plant mesophyll cells during feeding. Mol. Plant-Microbe Interact. 29:854-861.

Mukhtar, M. S., Carvunis, A. R., Dreze, M., Epple, P., Steinbrenner, J., Moore, J., Tasan, M., Galli, M., Hao, T., Nishimura, M. T., Pevzner, S. J., Donovan, S. E., Ghamsari, L., Santhanam, B., Romero, V., Poulin, M. M., Gebreab, F., Gutierrez, B. J., Tam, S., Monachello, D., Boxem, M., Harbort, C. J., McDonald, N., Gai, L., Chen, H., He, Y., Vandenhaute, J., Roth, F. P., Hill, D. E., Ecker, J. R., Vidal, M., Beynon, J., Braun, P., and Dangl, J. L. 2011. Independently evolved virulence effectors converge onto hubs in a plant immune system network. Science 333:596-601.

Munkvold, K. R., and Martin, G. B. 2009. Advances in experimental methods for the elucidation of Pseudomonas syringae effector function with a focus on AvrPtoB. Mol. Plant Pathol. 10:777-793.

Nielsen, H., Engelbrecht, J., Brunak, S., and von Heijne, G. 1997. Identification of prokaryotic and eukaryotic signal peptides and prediction of their cleavage sites. Protein Eng. 10:1-6.

Nomura, K., Mecey, C., Lee, Y. N., Imboden, L. A., Chang, J. H., and He S. Y. 2011. Effector-triggered immunity blocks pathogen degradation of an immunity-associated vesicle traffic regulator in Arabidopsis. Proc. Natl. Acad. Sci. USA 108:10774-10779.

Pais, M., Win, J., Yoshida, K., Etherington, G. J., Cano, L. M., Raffaele, S., Banfield, M. J., Jones, A., Kamoun, S., and Saunders, D. G. 2013. From pathogen genomes to host plant processes: The power of plant parasitic oomycetes. Genome Biol. 14:211.

Petersen, T. N., Brunak, S., von Heijne, G., and Nielsen, H. 2011. SignalP 4.0: Discriminating signal peptides from transmembrane regions. Nat. Methods 8:785-786.

Petre, B., Lorrain, C., Saunders, D. G., Win, J., Sklenar, J., Duplessis, S., and Kamoun, S. 2016. Rust fungal effectors mimic host transit peptides to translocate into chloroplasts. Cell. Microbiol. 18:453-465.

Reithinger, J. H., Kim, J. E., and Kim, H. 2013. Sec62 protein mediates membrane insertion and orientation of moderately hydrophobic signal anchor proteins in the endoplasmic reticulum (ER). J. Biol. Chem. 288: 18058-18067.

Robinson, P. J., Findlay, J. E., and Woolhead, C. A. 2012. Compaction of a prokaryotic signal-anchor transmembrane domain begins within the ribosome tunnel and is stabilized by SRP during targeting. J. Mol. Biol. 423:600-612.

Saunders, D. G. O., Win, J., Kamoun, S., and Raffaele, S. 2014. Twodimensional data binning for the analysis of genome architecture in filamentous plant pathogens and other eukaryotes. Pages 29-51 in: PlantPathogen Interactions Methods and Protocols, 2nd ed. P. Birch, J. T. Jones, and J. I. B. Bos, eds. Humana Press, New York.

Sohn, K. H., Lei, R., Nemri, A., and Jones, J. D. 2007. The downy mildew effector proteins ATR1 and ATR13 promote disease susceptibility in Arabidopsis thaliana. Plant Cell 19:4077-4090.

Sonah, H., Deshmukh, R. K., and Bélanger, R. R. 2016. Computational prediction of effector proteins in fungi: Opportunities and challenges. Front. Plant Sci. 7:126.

Sparkes, I. A., Runions, J., Kearns, A., and Hawes, C. 2006. Rapid, transient expression of fluorescent fusion proteins in tobacco plants and generation of stably transformed plants. Nat. Protocols 1:2019-2025.
Sperschneider, J., Dodds, P. N., Gardiner, D. M., Manners, J. M., Singh, K. B., and Taylor, J. M. 2015. Advances and challenges in computational prediction of effectors from plant pathogenic fungi. PLoS Pathog. 11: e1004806.

Sperschneider, J., Ying, H., Dodds, P. N., Gardiner, D. M., Upadhyaya, N. M., Singh, K. B., Manners, J. M., and Taylor, J. M. 2014. Diversifying selection in the wheat stem rust fungus acts predominantly on pathogenassociated gene families and reveals candidate effectors. Front. Plant Sci. 5:372.

Stam, R., Jupe, J., Howden, A. J. M., Morris, J. a., Boevink, P. C., Hedley, P. E., and Huitema, E. 2013. Identification and characterisation CRN effectors in Phytophthora capsici shows modularity and functional diversity. PLoS One 8:e59517.

Stassen, J. H., and Van den Ackerveken, G. 2011. How do oomycete effectors interfere with plant life? Curr. Opin. Plant Biol. 14:407-414.

Stotz, H. U., Mitrousia, G. K., de Wit, P. J. G. M., and Fitt, B. D. L. 2014. Effector-triggered defence against apoplastic fungal pathogens. Trends Plant Sci. 19:491-500.

Sugio, A., MacLean, A. M., Kingdom, H. N., Grieve, V. M., Manimekalai, R., and Hogentout, S. 2011. Phytoplama effectors: From plant development to defense against insects. Annu. Rev. Phytopathol. 49:175-195.

Szurek, B., Marois, E., Bonas, U., and Van den Ackerveken, G. 2001. Eukaryotic features of the Xanthomonas type III effector AvrBs3: Protein domains involved in transcriptional activation and the interaction with nuclear import receptors from pepper. Plant J. 26:523-534.

Szurek, B., Rossier, O., Hause, G., and Bonas, U. 2002. Type III-dependent translocation of the Xanthomonas AvrBs3 protein into the plant cell Mol. Microbiol. 46:13-23.

Takemoto, D., Jones, D. A., and Hardham, A. R. 2003. GFP-tagging of cell components reveals the dynamics of subcellular re-organization in response to infection of Arabidopsis by oomycete pathogens. Plant J. 33: 775-792.

Thomas, W. J., Thireault, C. A., Kimbrel, J. A., and Chang, J. H. 2009. Recombineering and stable integration of the Pseudomonas syringae pv. syringae $61 \mathrm{hrp} / \mathrm{hrc}$ cluster into the genome of the soil bacterium Pseudomonas fluorescens Pf0-1. Plant J. 60:919-928.

Toruno, T. Y., Stergiopoulos, I., and Coaker, G. 2016. Plant-pathogen effectors: Cellular probes interfering with plant defenses in spatial and temporal manners. Annu. Rev. Phytopathol. 54:419-441.

Tseng, T.-T., Tyler, B. M., and Setubal, J. C. 2009. Protein secretion systems in bacterial-host associations, and their description in the gene ontology. BMC Microbiol. 9:S2.

Tyler, B. M. 2017. The fog of war: How network buffering protects plants' defense secrets from pathogens. PLoS Genet. 13:e1006713.

Tyler, B. M., Kale, S. D., Wang, Q., Tao, K., Clark, H. R., Drews, K., Antignani, V., Rumore, A., Hayes, T., Plett, J. M., Fudal, I., Gu, B., Chen, Q., Affeldt, K. J., Berthier, E., Fischer, G. J., Dou, D., Shan, W., Keller, N. P., Martin, F., Rouxel, T., and Lawrence, C. B. 2013. Microbeindependent entry of oomycete RxLR effectors and fungal RxLR-like effectors into plant and animal cells is specific and reproducible. Mol. Plant-Microbe Interact. 26:611-616.

Upadhyaya, N. M., Ellis, J. G., and Dodds, P. N. 2014a. A bacterial type III secretion-based delivery system for functional assays of fungal effectors in cereals. Methods Mol. Biol. 1127:277-290.

Upadhyaya, N. M., Mago, R., Staskawicz, B. J., Ayliffe, M. A., Ellis, J. G., and Dodds, P. N. 2014b. A bacterial type III secretion assay for delivery of fungal effector proteins into wheat. Mol. Plant-Microbe Interact. 27: 255-264.

Vleeshouwers, V. G. A. A., Finkers, R., Budding, D. J., Visser, M., Jacobs, M. M. J., van Berloo, R., Pel, M., Champouret, N., Bakker, E., Krenek, P., Rietman, H., Huigen, D. J., Hoekstra, R., Goverse, A., Vosman, B., Jacobsen, E., and Visser, R. G. F. 2011a. SolRgene: An online database to explore disease resistance genes in tuber-bearing Solanum species. BMC Plant Biol. 11:116.

Vleeshouwers, V. G. A. A., and Oliver, R. P. 2014. Effectors as tools in disease resistance breeding against biotrophic, hemibiotrophic, and necrotrophic plant pathogens. Mol. Plant-Microbe Interact 27:196-206.

Vleeshouwers, V. G. A. A., Raffaele, S., Vossen, J., Champouret, N., Oliva, R., Segretin, M. E., Rietman, H., Cano, L. M., Lokossou, A. A., Kessel, G. J. T., Pel, M., and Kamoun, S. 2011b. Understanding and exploiting late blight resistance in the age of effectors. Annu. Rev. Phytopathol. 49: 507-531.

Vleeshouwers, V. G. A. A., Rietman, H., Krenek, P., Champouret, N., Young, C., Oh, S.-K., Wang, M., Bouwmeester, K., Vosman, B., Visser, R. G. F., Jacobsen, E., Govers, F., Kamoun, S., and Van der Vossen, E. A. G. 2008. Effector genomics accelerates discovery and functiona profiling of potato disease resistance and Phytophthora infestans avirulence genes. PLoS One 3:e2875. 
von Heijne, G. 1998. Life and death of a signal peptide. Nature 396: 111-113.

Wang, Q., Han, C., Ferreira, A. O., Ye, W., Tripathy, S., Kale, S. D., Gu, B., Wang, X., Yu, X., Liu, T., Yao, Y., Wang, X., Sheng, Y., Sui, Y., Zhang, Z., Cheng, B., Dong, S., Shan, W., Zheng, X., Dou, D., Tyler, B. M., and Wang, Y.. 2011. Transcriptional programming and functional interactions within the Phytophthora sojae RXLR effector repertoire. Plant Cell 23:2064-2086.

Wang, S., Boevink, P. C., Welsh, L., Zhang, R., Whisson, S. C., and Birch, P. R. J. 2017. Delivery of cytoplasmic and apoplastic effectors from Phytophthora infestans haustoria by distinct secretion pathways. New Phytol. 216:205-215.

Wawra, S., Belmonte, R., Löbach, L., Saraiva, M., Willems, A., and van West, P. 2012. Secretion, delivery and function of oomycete effector proteins. Curr. Opin. Microbiol. 15:685-691.

Weinthal, D. M., Barash, I., Tzfira, T., Gaba, V., Teper, D., Sessa, G., and Manulis-Sasson, S. 2011. Characterization of nuclear localization signals in the type III effectors HsvG and HsvB of the gall-forming bacterium Pantoea agglomerans. Microbiology 157:1500-1508.

Wessling, R., Epple, P., Altmann, S., He, Y., Yang, L., Henz, S. R., McDonald, N., Wiley, K., Bader, K. C., Glasser, C., Mukhtar, M. S., Haigis, S., Ghamsari, L., Stephens, A. E., Ecker, J. R., Vidal, M., Jones, J. D., Mayer, K. F., Ver Loren van Themaat, E., Weigel, D., Schulze-Lefert, P., Dangl, J. L., Panstruga, R., and Braun, P. 2014. Convergent targeting of a common host protein-network by pathogen effectors from three kingdoms of life. Cell Host Microbe 16: 364-375.
Whisson, S. C., Boevink, P. C., Moleleki, L., Avrova, A. O., Morales, J. G., Gilroy, E. M., Armstrong, M. R., Grouffaud, S., van West, P., Chapman, S., Hein, I., Toth, I. K., Pritchard, L., and Birch, P. R. 2007. A translocation signal for delivery of oomycete effector proteins into host plant cells. Nature 450:115-118.

Win, J., Chaparro-Garcia, A., Belhaj, K., Saunders, D. G., Yoshida, K., Dong, S., Schornack, S., Zipfel, C., Robatzek, S., Hogenhout, S. A., and Kamoun, S. 2012. Effector biology of plant-associated organisms: Concepts and perspectives. Cold Spring Harb. Symp. Quant. Biol. 77:235-247.

Wroblewski, T., Tomczak, A., and Michelmore, R. 2005. Optimization of Agrobacterium-mediated transient assays of gene expression in lettuce, tomato and Arabidopsis. Plant Biotechnol. J. 3:259-273.

Xu, N., Luo, X., Li, W., Wang, Z., and Liu, J. 2017. The bacterial effector AvrB-induced RIN4 hyperphosphorylation is mediated by a receptorlike cytoplasmic kinase complex in Arabidopsis. Mol. Plant-Microbe Interact. 30:502-512

Yu, X., Tang, J., Wang, Q., Ye, W., Tao, K., Duan, S., Lu, C., Yang, X., Dong, S., Zheng, X. and Wang, Y. 2012. The RxLR effector Avh241 from Phytophthora sojae requires plasma membrane localization to induce plant cell death. New Phytol. 196:247-260.

Zhang, M., Li, Q., Liu, T., Liu, L., Shen, D., Zhu, Y., Liu, P., Zhou, J. M., and Dou, D. 2015. Two cytoplasmic effectors of Phytophthora sojae regulate plant cell death via interactions with plant catalases. Plant Physiol. 167:164-175.

Zückert, W. R. 2014. Secretion of bacterial lipoproteins: Through the cytoplasmic membrane, the periplasm and beyond. Biochim. Biophys. Acta 1843:1509-1516. 